Negi, M. S., M. Devic, M. Delseny and M. LaKshmikuMARAN (2000): Identification of AFLP fragments linked to seed coat colour in Brassica juncea and conversion to a SCAR marker for rapid selection. Theor. Appl. Genet. 101: $146-152$.

NEI, M. (1973): Analysis of gene diversity in subdivided populations. Proc Natl Acad Sci USA 70: 3321-3323.

Nicese, F. P., J. I. Hormaza and G. H. McGranahan (1998): Molecular characterization and genetic relatedness among walnut (Juglans regia L.) genotypes based on RAPD markers. Euphytica 101: 199-206.

PARAN, I. and R. W. Michelmore (1993): Development of reliable PCR-based markers linked to downy mildew resistance genes in lettuce. Theor. Appl. Genet. 85: 985-993.
SAmbrook, J., R. MANiatis and E. F. Fritsch (1989): Molecular cloning; A laboratory manual. Cold Spring Harbor, New York.

Sakamoto, S., H. Kudo, S. Suzuki, S. Sassa, S. Yoshimura, T. Nakayama, M. Maemura, T. Mitamura, Z. QI, X. D. LiU, Y. YAGishita and A. Asai (1996): Pharmacotherapeutic effects of toki-shakuyaku-san on leukorrhagia in young women. Am. J. Chin. Med. 24: 165-168.

Williams, J. G. K., A. R. KubELIK, K. J. LivaK, J. A. RAFALSKI and S. V. TINGEY (1990): DNA polymorphism amplified by arbitrary primers are useful as genetic markers. Nucleic Acid Res. 18: 6531-6535.

\title{
Genetic Diversity of Two Evergreen Oaks [Quercus suber (L.) and Quercus ilex subsp. rotundifolia (Lam.)] in Portugal using AFLP Markers
}

\author{
By A. C. Coelho ${ }^{1), 2)}$, M. B. Lima ${ }^{3)}$, D. Neves ${ }^{4)}$ and A. Cravador ${ }^{1)}$
}

(Received 24 ${ }^{\text {th }}$ June 2005)

\begin{abstract}
The genetic variability of cork oak (Quercus suber, L.) in Portugal was evaluated by AFLP using five primer combinations. Three hundred and thirteen trees from three geographically contrasting regions exhibited a high level of genetic variation. The genetic profile of each individual is composed of 291 loci, randomly positioned in the genome and consists of monomorphic and polymorphic fragments. Similarities and dissimilarities among the individuals were quantitatively evaluated by numerical taxonomy. The overall sample shows a proportion of AFLP polymorphic markers of $71 \%$, denoting a high level of variability. Ninety percent of the polymorphic markers identified in cork oak genotypes are uniformly distributed throughout the cork oak populations of Algarve, Alentejo and Trás-os-Montes regions. The coefficients of genetic similarity vary from 0.61 to 0.88 implying that $60 \%$ of fragments found are common. A sample of 52 holm oak [Quercus ilex subsp. rotundifolia (Lam.)] trees from overlapping areas was also analysed by AFLP with the same five primer combinations. However the codification of markers together with those selected on cork oak profiles was feasible with only one

1) Universidade do Algarve, Faculdade de Engenharia dos Recursos Naturais, Campus de Gambelas, 8005-139 FARO, Portugal.

2) Universidade do Algarve, Escola Superior de Educação, Campus da Penha, 8005-139 FARO, Portugal.

$\left.{ }^{3}\right)$ Unidade de Taxonomia Numérica, Estação Agronómica Nacional, Quinta do Marquês, 2784-505 OEIRAS, Portugal.

4) Universidade do Algarve, Instituto Transfronteiriço Universitário para a Ciência, a Cultura e o Ambiente, Campus de Gambelas, 8005-139 FARO, Portugal.

A. CRAVADOR. e-mail: acravad@ualg.pt

A. C. CoelHo. e-mail: acoelho@ualg.pt
\end{abstract}

primer combination due to an apparent much higher polymorphism. AFLP and numerical taxonomy analysis enabled to differentiate the taxa and showed that the level of similarity observed between the profiles of the individuals from holm oak species was lower than that observed in cork oak, implying that apparently the degree of polymorphism is higher in $Q$. ilex subsp. rotundifolia than that quantified in $Q$. suber.

A Bayesian approach was used to assess $Q$. suber total genetic diversity $(\mathrm{Ht}=0.2534, \mathrm{P}<0.001)$ of which $1.7 \%$ $(F s t=0.0172, P<0.001)$ was assigned to differences among populations. Analysis of molecular variance (AMOVA) showed that most genetic variation is comprised within populations $(96 \%)$ while $3.6 \%$ is among populations ( $\Phi$ st $=0.036, P<0.001)$. Differences among populations within geographic regions account for $2.6 \%$ ( $\Phi$ sc $=0.026, P<0.001)$ of the total variation and only $1.3 \%$ ( $\Phi$ ct $=0.013, P=0.007$ ) is attributed to variation among regions denoting little differentiation of populations over a range of $700 \mathrm{~km}$.

Key words: AFLP, genetic diversity, genetic introgression, Quercus suber (L.), Quercus ilex subsp. rotundifolia (Lam.)

\section{Introduction}

Cork oak (Quercus suber L.), an evergreen species, is mainly distributed in the western Mediterranean Basin. The largest stands, covering about 700.000 ha are located in Portugal and correspond to $21 \%$ of the forest area in Portugal and to $30 \%$ of the world cork producing area. Cork oak plantations are very important for the economy and constitute a social and environmental issue that has to be taken into consideration as the unparalleled decline occurring in the Iberian Peninsula 
and in Morocco is nowadays threatening the entire ecosystem. The main contributing factor to this decline has been described in Portugal and Spain as a root disease caused by the soil born pathogenic oomycete Phytophthora cinnamomi (BRASIER et al., 1993; MOREIRAMARCElino, 2001; Moreira and Martins et al., 2005). The increasing use of synthetic stoppers replacing cork is an additional factor that in conjunction with the decline disease strongly increases the threat of the disappearance of this ecosystem in the medium term. Conservation concerns about the danger of extinction threatening thousands of tree species throughout the world stimulated intraspecific genetic variation studies, an essential prerequisite for the implementation of conservation strategies (NEWTON et al., 1999).

Hybridisation of Q. suber with other Quercus species, namely with the complex Quercus aggr. ilex L., including $Q$. ilex and $Q$. ilex subsp. rotundifolia (Lam.) (Flora Europaea, 1993; Flora de España, 1981; LEBRETON et al., 2001) all evergreen oaks with a coincident geographic distribution is reported as a natural occurrence and could be regarded as one factor contributing to increase the genetic diversity in cork oak. It is supported by isozyme markers analysis (ELENA-Rosselló et al., 1992; TOUMI and LUMARET, 1998) and by evidence of gene flow between these species on the basis of a PCR-RFLP analysis showing shared patterns of chloroplast and mitochondrial DNA (BELAHBIB et al., 2001). Analysis of chloroplast haplotypes derived from combination of variants of PCR-RFLP fragments in $Q$. suber and $Q$. ilex strongly supports the existence of asymmetric interspecific cytoplasmic introgression clearly in the main direction $Q$. ilex (female) x Q. suber (male) (JIMÉNEZ et al., 2004).

Intraspecific morphological variation has also been widely reported in oaks and natural interspecific hybridisation has been suggested as an important factor (Trelease, 1924; Natividade, 1936; CAMUs, 1938; PAlmer, 1948; Muller, 1952; Hardin, 1975; Rushton, 1993; SPELlENBERG, 1995; BACILIERI et al., 1996; HOWARD et al., 1997). Also, Q. suber has been described as an extremely polymorphous species with many overlapping morphological attributes, mainly distinguishable by certain traits of the leaves, fruits and cupules, and it has been suggested that multifactorial mutations and hybridisation played a determinant role in the phylogenetic development of $Q$. suber (NATIVIDADE, 1950).

Isozymes markers have been used to assess genetic variation and differentiation among populations in cork oak of the Mediterranean Basin (ELENA-RossElló and CABRERA, 1996; Toumi and LumARET, 1998; JimÉnEZ et al., 1999) and to compare Q. suber, Q. ilex, Q. coccifera and $Q$. alnifolia, four Mediterranean evergreen oak species (TOUMI and LuMARET, 2001). Genetic diversity has also been assessed in $Q$. robur and $Q$. petrae using microsatellites and Amplified Fragment Length Polymorphism (AFLP) markers (COTTRELL et al., 2003; MARIETTE et al., 2002; COART et al., 2002), in California red oaks (DoDD and KASHANI, 2003) using AFLP, and in Mexican oaks using RAPD's markers (ALFONSO-CoRRADO et al., 2004).
Conservation policies will depend to a large extent on our knowledge of historic and genetic relationship among these species. AFLP has proved to be a powerful marker technology to assess diversity and genetic differentiation among plant populations, to help establish reliable taxonomic relationships between species or different genotypes of the same species (MARIETTE et al., 2002; VAN DER MERWE et al., 2000; MACE et al., 1999; Zhang et al., 1999; Singh et al., 1999; PAUL et al., 1997), check genetic stability in somatic embryos (HORNERO et al., 2001a) or identify molecular markers linked to disease resistance and economically important traits (CERVERA et al., 1996; THOMAs et al., 1995). In Q. suber, quality of cork is economically the most relevant trait. In spite of the economic importance of this renewable material, little is known about both the biological and the genetic mechanisms involved in its formation. AFLP could be a useful approach to identify molecular markers related to cork synthesis.

In contrast to SSR and isozyme markers, AFLPs are dominant markers and the genotypic information acquired from each locus is restricted as a result of dominant inheritance. However, AFLP markers do not require sequence information and a large number can be assayed on a single gel providing quicker information on an enlarged number of loci.

Human intervention through extensive plantations and systematic clear-cutting in forests with the objective of empirically selecting varieties with acceptable levels of cork quality is supposed to have strongly contributed to the homogenisation of populations of $Q$. suber in Portugal. The effect of acorn selection could have played in favour of holm oak expansion as acorns from this species are preferred to feed livestock. However, barking and acorn utilization were illegal (MATTOso, 1947) until exploitation of cork become systematic. As a matter of fact the importance of cork oak plantations is ancient in Portugal. The first protective measures date from 1300s. Exportation of cork to North Europe is older than 1438 when regal rights to Portuguese merchants were ratified (Viterbo, 1904; Barros Bernardo, 1942). Human pressure in the development of cork oak plantations has been continuing for at least seven centuries.

The objectives of the present work were to assess the level of genetic diversity of $Q$. suber within and among populations of three geographically contrasting regions of Portugal using AFLP methodology, verify the influence of the anthropogenic pressure on the population differentiation and the effect of geographic discontinuities on genetic variation. A further objective was to ascertain to what extent these nuclear markers are useful to estimate gene flow between $Q$. suber and $Q$. ilex subsp. rotundifolia, two species that have an overlapping geographic distribution. Lastly, we have also intended to disclose putative AFLP markers linked to cork quality.

\section{Material and Methods}

\section{Plant material}

The material used in the present study was collected from productive stands, corresponding to 19 populations 


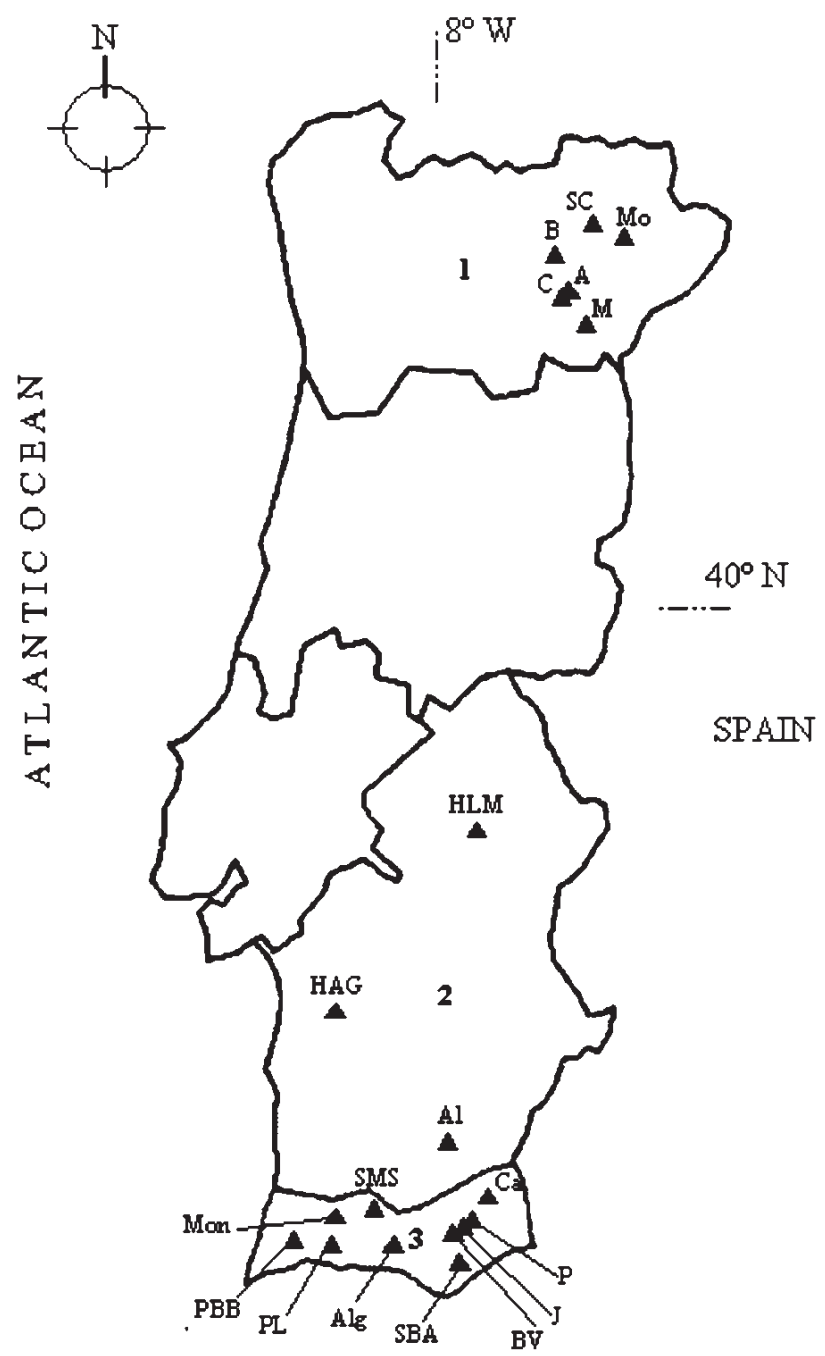

\begin{tabular}{|c|c|c|c|}
\hline \multicolumn{4}{|c|}{$\begin{array}{l}\text { 1. NORTH REGION } \\
\text { TRÁS-OS-MONTES }\end{array}$} \\
\hline \multirow{2}{*}{$\begin{array}{l}\text { Geographical } \\
\text { location }\end{array}$} & \multirow{2}{*}{ Code } & \multicolumn{2}{|c|}{ Number of oak trees } \\
\hline & & Cork & Holm \\
\hline Adeganha & $\mathrm{A}$ & 3 & - \\
\hline Benlhevai & B & 2 & - \\
\hline Cardanha & $\mathrm{C}$ & 4 & - \\
\hline Maçores & $\mathrm{M}$ & 15 & - \\
\hline Morais & Mo & 58 & 8 \\
\hline Sta Combinha & $\mathrm{SC}$ & 16 & 2 \\
\hline \multicolumn{4}{|c|}{ 2. ALENTEJO } \\
\hline \multirow{2}{*}{$\begin{array}{l}\text { Geographical } \\
\text { location }\end{array}$} & \multirow{2}{*}{ Code } & \multicolumn{2}{|c|}{ Number of oak trees } \\
\hline & & Cork & Holm \\
\hline Almodôvar & $\mathrm{Al}$ & 14 & 14 \\
\hline H.A.-Grândola & HAG & 19 & - \\
\hline H.L.-Montargil & HLM & 58 & - \\
\hline \multicolumn{4}{|c|}{ 3. ALGARVE } \\
\hline \multirow{2}{*}{$\begin{array}{l}\text { Geographical } \\
\text { location }\end{array}$} & \multirow{2}{*}{ Code } & \multicolumn{2}{|c|}{ Number of oak trees } \\
\hline & & Cork & Holm \\
\hline Algoz & Alg & 6 & 1 \\
\hline Cachopo & $\mathrm{Ca}$ & 17 & 3 \\
\hline Barranco do Velho & BV & 15 & 8 \\
\hline Javali & $\mathrm{J}$ & 4 & - \\
\hline Monchique & Mon & 12 & - \\
\hline Parises & $\mathbf{P}$ & 12 & - \\
\hline Pincho/B. Bravura & PBB & 17 & - \\
\hline Porto Lagos & PL & 2 & 1 \\
\hline S. Brás Alportel & SBA & 22 & 14 \\
\hline S. Marcos da Serra & SMS & 17 & 1 \\
\hline
\end{tabular}

Figure 1. - Geographic location in Portugal of the 313 cork oak (Q. suber) trees and 52 holm oak (Q. ilex subsp. rotundifolia) trees included in the AFLP study. Information about the number of trees analysed by AFLP coming from each location.

distributed in three geographically contrasting regions of Portugal (Fig. 1). A total of 365 trees were sampled throughout Portugal: 313 Q. suber trees and 52 Q. ilex subsp. rotundifolia trees; all individuals sampled had typical bark and leaf characters. Cork quality was assessed for 98 individuals on a basis of porosity variation using computer imaging analysis (FONSECA et al., 1992).

\section{DNA extraction and AFLP analysis}

Young leaves were collected from each tree during April and June and stored at $-80^{\circ} \mathrm{C}$ until extraction. Total DNA was extracted from samples using a Qiagen Dneasy kit with the following modifications: leaves were powdered in liquid nitrogen using a conic plastic tip fixed to a drill and soaked for a few seconds in AP1 buffer included in the kit. The DNA extractions were stored at $-20^{\circ} \mathrm{C}$ until required. Concentration of DNA was determined by spectrophotometry. AFLP fingerprints were generated based on the protocol of Vos et al. (1995) with some modifications. Genomic DNA (600 ng) was restricted with $E c o R I$ and $M s e I(2.5 \mathrm{U} / \mu \mathrm{l}$ each) in a restriction buffer (50 mM TRIS-HCl pH-7.5, $50 \mathrm{mM} \mathrm{Mg}$ acetate, $250 \mathrm{mM} \mathrm{K}$ acetate) in a total volume of $25 \mu \mathrm{l}$
(AFLP Core Reagent Kit, GIBCO BRL) for $2 \mathrm{~h}$ at $37^{\circ} \mathrm{C}$. After enzyme inactivation at $70^{\circ} \mathrm{C}$ for $15 \mathrm{~min} E c o R I$ and MseI adapters were ligated to DNA digested fragments. The adapter-ligated DNA was pre-amplified using the following cycling parameters: 28 cycles of $30 \mathrm{~s}$ at $94^{\circ} \mathrm{C}$; $60 \mathrm{~s}$ at $56^{\circ} \mathrm{C}$ and $60 \mathrm{~s}$ at $72^{\circ} \mathrm{C}$. The pre-amplified DNA was diluted in a ratio of 1:10 and was used as a template for the selective amplification which involved the use of 5 different primer pair combinations (EcoRI-XXX and $M s e \mathrm{I}-\mathrm{XXX})$ namely I1 (E-ACC/M-ATT); I2 $(E$ $\mathrm{ACC} / M-\mathrm{ACC})$; I3 ( $E$-ATG/ $M$-ACC); I9 ( $E$-ACC/ $M$-TGG); I10 ( $E$-ACC/M-TTG). The cycling parameters were: 13 cycles with denaturation of $30 \mathrm{~s}$ at $94^{\circ} \mathrm{C}$, primer annealing of $30 \mathrm{~s}$ at $65^{\circ} \mathrm{C}$. The annealing temperature was lowered by $0.7^{\circ} \mathrm{C}$ per cycle during the first 12 cycles until reaching $56^{\circ} \mathrm{C}$. Polymerisation of $60 \mathrm{~s}$ at $72^{\circ} \mathrm{C}$, and then 18 cycles of $30 \mathrm{~s}$ at $94^{\circ} \mathrm{C}, 30 \mathrm{~s}$ at $56^{\circ} \mathrm{C}$ and $60 \mathrm{~s}$ at $72^{\circ} \mathrm{C}$. The samples were resolved on $5.7 \%$ acrylamide gel and autoradiographed.

\section{Isolation and sequencing of fragments}

AFLP fragments of cork oak trees were transferred from the polyacrylamide gel to Whatman paper (3MM). A piece of the dried gel containing the band of interest 
was cut out and soaked in $40 \mu \mathrm{l}$ of $\mathrm{H}_{2} \mathrm{O}$ for $10 \mathrm{~min}$ in ice. The sample was then heated for $15 \mathrm{~min}$ at $95^{\circ} \mathrm{C}$ and cooled again on ice. After a brief centrifugation, $5 \mu \mathrm{l}$ of the supernatant were transferred to another tube. Reamplification of the recovered fragment was performed under the same conditions and with the same primer combination used in the reaction which generated the product of interest. The re-amplified PCR product was run on a $2 \%$ agarose gel, cut out and purified using Qiaquick PCR Purification Kit (Qiagen) and finally cloned into the pCRII Topo vector using TA Cloning Kit (Invitrogen). Manufacturer's instructions for these kits were followed throughout. The fragments were sequenced using an Applied Biosystems PRISM Ready Reaction DyeDeoxy Terminator cycle sequencing kit and an automated sequencer.

\section{Data analysis}

The five primer combinations used on the selective amplifications (I1, I2, I3, I9, I10) produced DNA fragments, that were scored as present/absent in each studied object (313 cork oak and 2 holm oak trees) herein named OTUs (Operational Taxonomic Unit). An additional analysis was performed applying one primer combination (I9) to 313 cork oak and 52 holm oak trees.

These data were analysed using the NTSYS-pc (Numerical Taxonomy and Multivariate Analysis System), version 2.0 of computer programmes, to determine the similarities among each pair of selected oak trees. The original data matrices of $\mathrm{X}$ characters $\mathrm{x} Y$ OTUs were subjected to standard numerical procedures (SNEATH and Sokal, 1973) and similarities among the OTUs were computed using the Jaccard coefficient. The OTUs were clustered by the UPGMA (Unweighted Pair Group Method) using arithmetic averages, in order to present the results in the form of a phenogram. Principal coordinates analysis (GowER and Ross, 1969) of the similarity matrix was performed, and the coordinates of the 315 and 365 OTUs were computed for the axes 1, 2 or 1, 3. A MST (Minimum Spanning Tree) was also computed from the distance matrix, and this was superimposed onto the projections of the 365 OTUs obtained from the principal coordinates analysis.

Genetic diversity and differentiation statistics were calculated using the programme Aflpsurv V.1.0 (VEKEMANS, 2001). Allelic frequencies at AFLP loci were computed from the observed frequencies of fragments using the Bayesien approach proposed by ZHivotosky (1999) for diploid species, assuming some deviation from Hardy Weinberg genotypic proportions. This deviation was accounted for through the use of inbreeding coefficients computed in other populations of $Q$. suber (Fis $=0.119$ and 0.173 ) and also of a hypothesised value of Fis $=0.15$ (see discussion). The significance of $F s t$ was obtained by means of 1000 random permutations of individuals among populations or species.

Analysis of molecular variance (AMOVA; ExCOFFIER et al., 1992) was used to investigate the partitioning of genetic variation among geographic groups of populations, among populations within these groups and within populations without regional structuring of $Q$. suber. The input file composed of dominant AFLP markers for
313 individuals located in three different geographic regions of Portugal (Algarve, Alentejo and Trás-osMontes) was obtained with the above five different primer combinations. For each AFLP locus the presence (1) or absence (0) of the amplified DNA fragment was considered as the molecular phenotype where the dominance of the marker allele (fragment present) over the null allele (fragment absent) is always assumed. The multilocus AFLP phenotypes are treated as haplotypes and the frequency of the marker allele at each locus can be inferred from the frequency of the AFLP fragment in the sample. In AMOVA the information on DNA haplotype divergence is incorporated into an analysis of variance format derived from a matrix of squared-distances among all pairs of haplotypes (EXCOFFIER et al., 1992). $\Phi$ values generated by the AMOVA program are used to estimate pair-wise genetic diversity, which is an analogue of the F-statistic. The significances of the different variance components were estimated from distributions generated from 100000 random permutations. These analyses were carried out using ARLEQUIN version 2.000 (SCHNEIDER et al., 2000). Additionally, the partition of variation in AFLP fragment patterns between $Q$. suber and $Q$. ilex subsp. rotundifolia species was calculated for AFLP data obtained with one primer combination and performed on 313 cork oak and 52 holm oak individuals.

\section{Results}

Genetic structure of $Q$. suber populations with AFLP markers

Five AFLP EcoRI and MseI selective primer combinations denominated I1, I2, I3, I9 and I10 were used to

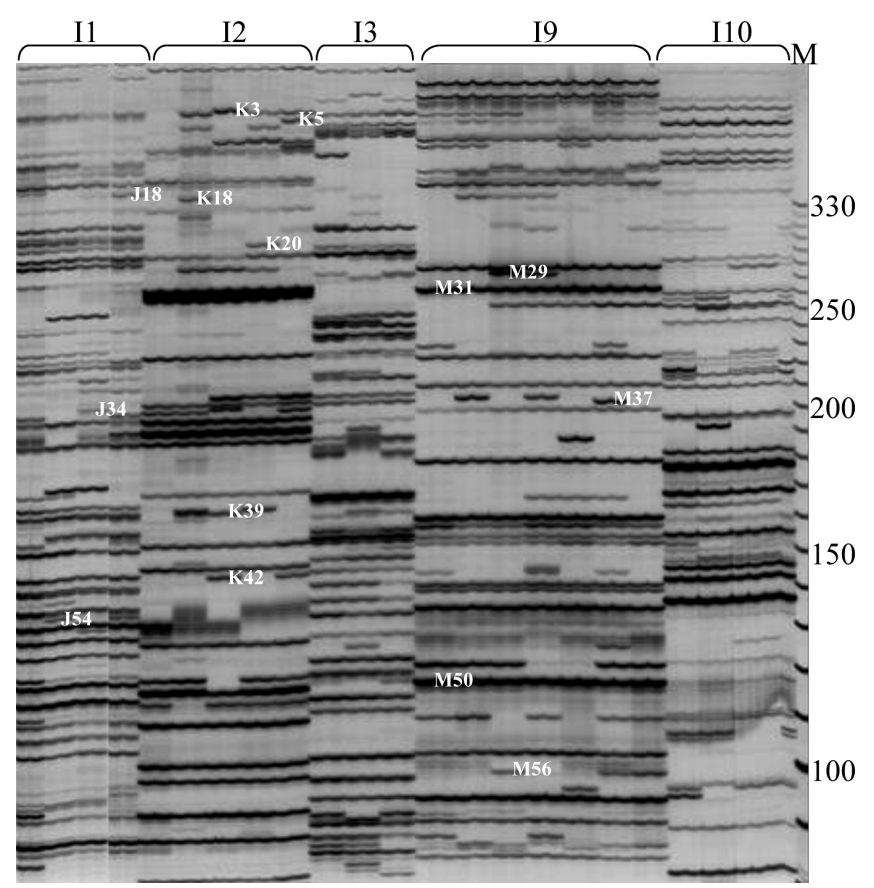

Figure 2. - AFLP analysis of Quercus suber. The AFLP fingerprints were generated using primer combinations I1, I2, I3, I9 and I10 to amplify genomic fragments from several genotypes. Fourteen AFLP fragments referred to in the results section are indicated. All samples are in duplicate. M: DNA ladder 30-330 bp. 
Table 1. - Parameters of the statistics of population genetic structure in $Q$. suber obtained by a Bayesian method assuming either Hardy-Weinberg genotypic proportions or fixed deviations based on prior information on the level of inbreeding (Fis). Calculations were performed using the programme Aflpsurv 1.0 (VeKEMANS, 2001). $n$ number of populations; $H t$ total diversity; $H w$ average diversity within populations; Fst differention between populations.

\begin{tabular}{|c|c|c|c|c|c|c|c|c|c|}
\hline Populations & $n$ & Fis & $H t$ & $H w$ & $\mathrm{SE}(H w)$ & $H b$ & $\mathrm{SE}(\boldsymbol{H b})$ & $F s t$ & P value \\
\hline \multirow{4}{*}{ Q. suber } & \multirow{4}{*}{19} & 0 & 0.2564 & 0.2507 & 0.00419 & 0.0057 & 0.002654 & 0.0222 & $<0.001$ \\
\hline & & 0.150 & 0.2534 & 0.2491 & 0.00537 & 0.0043 & 0.001651 & 0.0172 & $<0.001$ \\
\hline & & 0.119 & 0.2552 & 0.2511 & 0.00532 & 0.0040 & 0.001652 & 0.0159 & $<0.001$ \\
\hline & & 0.173 & 0.2522 & 0.2476 & 0.00539 & 0.0046 & 0.001654 & 0.0182 & $<0.001$ \\
\hline
\end{tabular}

Table 2. - Analysis of Molecular Variance (AMOVA) of the AFLP data obtained for 313 Q. suber individuals sampled from 19 populations, with and without regional structure.

\begin{tabular}{|c|c|c|c|c|c|c|}
\hline Source of variation & d.f. & $\begin{array}{l}\text { Sum of } \\
\text { squares }\end{array}$ & $\begin{array}{c}\text { Variance } \\
\text { components }\end{array}$ & $\begin{array}{l}\text { Percentage of } \\
\text { variance }\end{array}$ & $\Phi$ values & P value \\
\hline \multicolumn{7}{|l|}{ No regional Groups } \\
\hline Among populations & 18 & 817.079 & 1.06642 & 3.58 & $\Phi s \mathrm{t}=0.036$ & $<0.001$ \\
\hline Within populations & 294 & 8434.352 & 28.68827 & 96.42 & & $<0.001$ \\
\hline Total & 312 & 9251.431 & 29.75470 & & & \\
\hline \multicolumn{7}{|c|}{ Three Groups: Trás-os-Montes/Alentejo/Algarve } \\
\hline Among groups & 2 & 191.973 & 0.40033 & 1.34 & $\Phi \mathrm{ct}=0.013$ & 0.00724 \\
\hline $\begin{array}{l}\text { Among populations } \\
\text { within groups }\end{array}$ & 16 & 625.107 & 0.77290 & 2.59 & $\Phi \mathrm{sc}=0.026$ & $<0.001$ \\
\hline Within populations & 294 & 8434.352 & 28.68827 & 96.07 & $\Phi s t=0.039$ & $<0.001$ \\
\hline Total & 312 & 9251.431 & 29.86150 & & & \\
\hline
\end{tabular}

analyse 313 cork oak and two holm oak genotypes. The five selective primer pairs produced a total of 291 AFLP fragments, distinguished without ambiguity in $Q$. suber, of which 35 are present in all oak trees of both species and 84 are monomorphic across the cork oak genotypes. On the average, 41 polymorphic loci in $Q$. suber and 51 in the group of both species $Q$. suber and $Q$. ilex subsp. rotundifolia were selected for analysis in each one of the five primer combinations. AFLP molecular markers were identified with code letters J1 to J57 (combination I1); K1 to K55 (combination I2); L1 to L72 (combination I3); M1 to M56 (combination I9); N1 to N51 (combination I10). All individuals tested without exception displayed unique AFLP band patterns suggesting a high level of genetic variability. In $Q$. suber, 207 out of 291 AFLP fragments were polymorphic $(71 \%)$ and 84 were monomorphic. A representative AFLP profile obtained with primer combinations I1, I2, I3, I9 e I10 is shown for several genotypes of $Q$. suber (Fig. 2). Ninety percent of the polymorphic markers identified in cork oak genotypes are uniformly distributed through Algarve, Alentejo and Trás-os-Montes regions. However, a number of AFLP markers prevail in the genome of cork oak trees according to the region where they are located. For example J18, K20 and K42 prevail in Algarve; J34, K3, K18 and K39 prevail in Trás-os-Montes (Fig. 2). Marker M29 is present exclusively in eleven cork oak trees from
Algarve (Fig. 2). Moreover, this last marker is present in 44 holm oak trees (vide below).

A Bayesian based analysis (Aflpsurv programme) using 291 AFLP markers scored in 313 cork oak trees belonging to 19 populations show a total genetic diversity value $(H t)$ of 0.2534 , a mean gene diversity within populations value $(H w)$ of 0.24919 , a genetic differentiation among populations value $(H b)$ of 0.0043 and a Wright's fixation index value $(F s t)$ of $0.0172(\mathrm{P}<0.001)$ considering a Fis value of 0.15 (Table 1). This Fis value was previously used in genetic variability AFLP analysis of oak populations (COART et al., 2002) and is within the range of Fis values of $0.118,0.119$ and 0.173 obtained in genetic variation analysis of $Q$. suber populations with microsatellites (HORNERO et al., 2001b) and isoenzymes (JimÉnEz et al., 1999; ElenA-Rosselló and CABRERA, 1996) markers. Calculations of genetic diversity parameters are shown in Table 1 for several Fis values.

AFLP diversity and its partitioning among populations have been analysed for 19 populations of $Q$. suber without and with structure according to the regions of origin (Trás-os-Montes/Alentejo/Algarve). AMOVA analysis of the AFLP data sets showed that $96 \%$ of total genetic variation was attributed to differences among individuals within populations (Table 2). A small proportion of the total variation was assigned to differences 

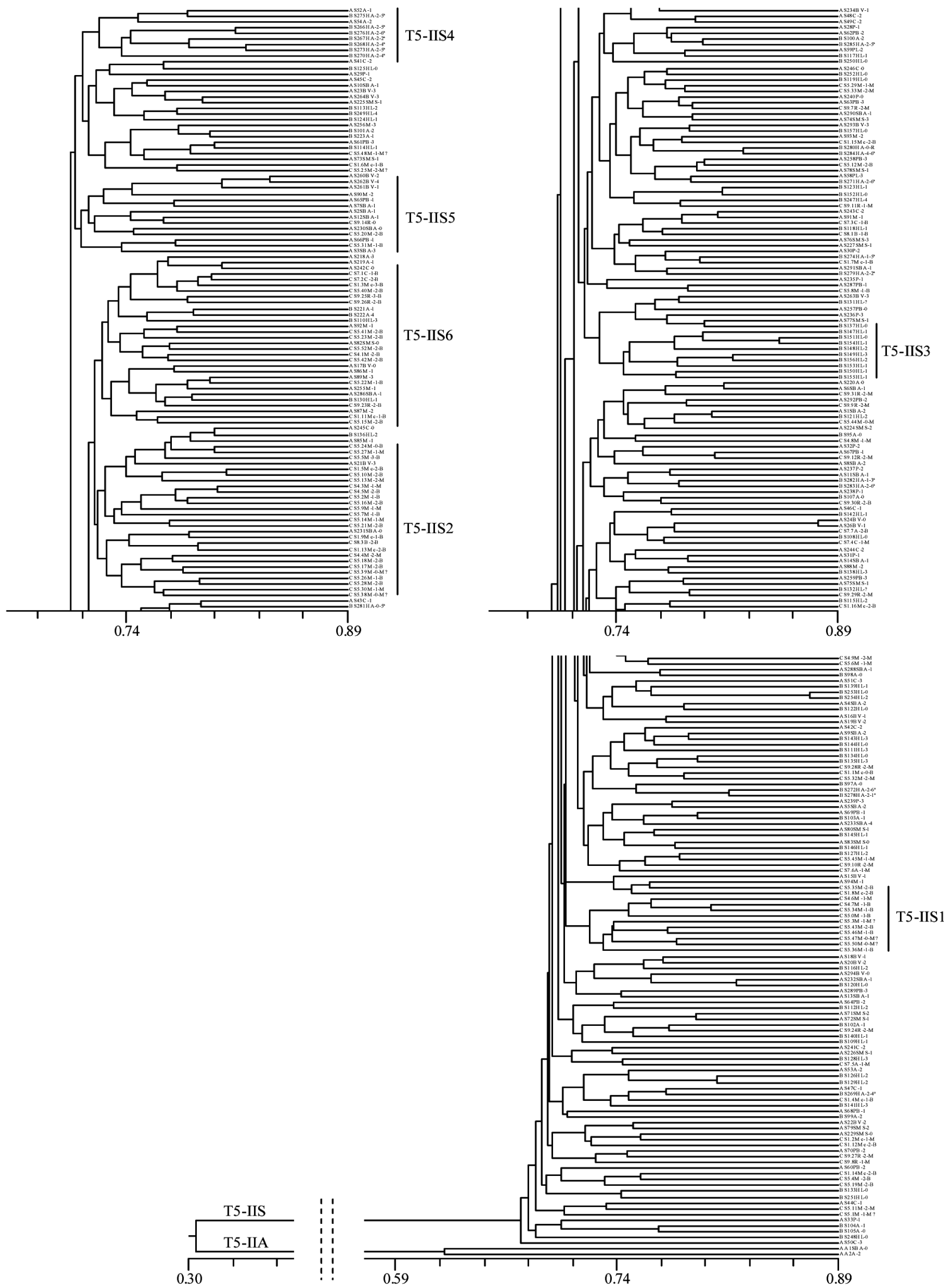

Figure 3. - Phenogram produced by Jaccard's coefficient and the UPGMA clustering method based on 291 AFLP markers in 313 cork oak and 2 holm oak accessions (coefficient of cophenetic correlation $r=0.8790$ ). 
among populations $(\Phi s t=0.036 ; \mathrm{P}<0.001)$. In the structured analysis of populations grouped according to geographic regions (Trás-os-Montes, Alentejo and Algarve), $1.3 \%$ of the genetic variance was attributed to differences among regions $(\Phi c t=0.013 ; \mathrm{P}=0.00724)$ and $2.6 \%$ to differences among populations within geographic regions $(\Phi s c=0.026 ; \mathrm{P}<0.001)$, denoting little differentiation of populations over a range of $700 \mathrm{~km}$. All the values obtained for the components of the molecular variance were significant $(\mathrm{P}=0.00724)$ or highly significant $(\mathrm{P}<0.001)$.

\section{Cluster and principal coordinates analyses.}

The AFLP profiles were used to make pair-wise comparisons of the genotypes based on both shared and unique amplification products to generate similarity matrices for the total data resulting from the sum of the five combinations. The degree of similarity between the cork oak trees was quantified using the Jaccard coefficient (NTSYS-pc statistical package, version 2.0, ROHLF 1998). Values of genetic similarity coefficient ranged from 0.88, observed between two cork oak trees from Javali site in the Algarve region, to 0.61 observed between cork oak trees from the Alentejo region.

Similarity matrices were submitted to cluster analysis by the unweighted pair group method using arithmetic averages (UPGMA, NTSYS-pc, version 2.0, RoHLF 1998). The co-phenetic correlation score $(r)$ was 0.87980 indicating a good fit and reliable phenogram. This one grouped the 315 oak trees into two major clusters, T5IIA and T5-IIS (Fig. 3). The group T5-IIA contained the accessions of the two holm oak trees included in this study. The large cluster T5-IIS containing all the 313 cork oak trees appears sub-divided into numerous groups. Considering a level of similarity over $71 \%$, five sub-groups can be distinguished according to a common location: T5-IIS5 comprises 11 trees from Algarve; T5IIS1 is composed of 10 trees from Morais stand (Trás-osMontes) and T5-IIS2 comprises 25, out of 27, trees from Trás-os-Montes; T5-IIS3 is composed of 9 trees and T5IIS4 comprises 7 out of 9 trees, located in two different stands, respectively, both from the Alentejo region. The AFLP markers referred to hereinbefore probably accounted for the formation of each of these sub-groups.

The quality of the cork produced was assayed for 98 cork oak trees from Trás-os-Montes region of which 57 were classified as good quality producers. The subgroup T5-IIS6 included 15 accessions from Trás-os-Montes characterized as producing cork of good quality. Trees clustered in this group and the AFLP markers common to them (J1, J54, K5 and M56; Fig. 2) are potential candidates to include in studies directed to the elucidation of the factors involved in the process of cork formation. None of these AFLP fragments is specific of the group.

Principal coordinates analysis was applied to the AFLP data to visualize in detail the genetic relationships between cork oak trees. The projection of spots representing the 315 oak trees onto the plane defined by the axes 1 and 3 is shown in Figure 4. In this projection the clusters formed in the phenogram are not visible. However, it is observed a tendency to the formation of two large and dispersed groups separated on the plot by a dashed line. The projection of the 291 AFLP fragments onto the same plane reveals the molecular markers

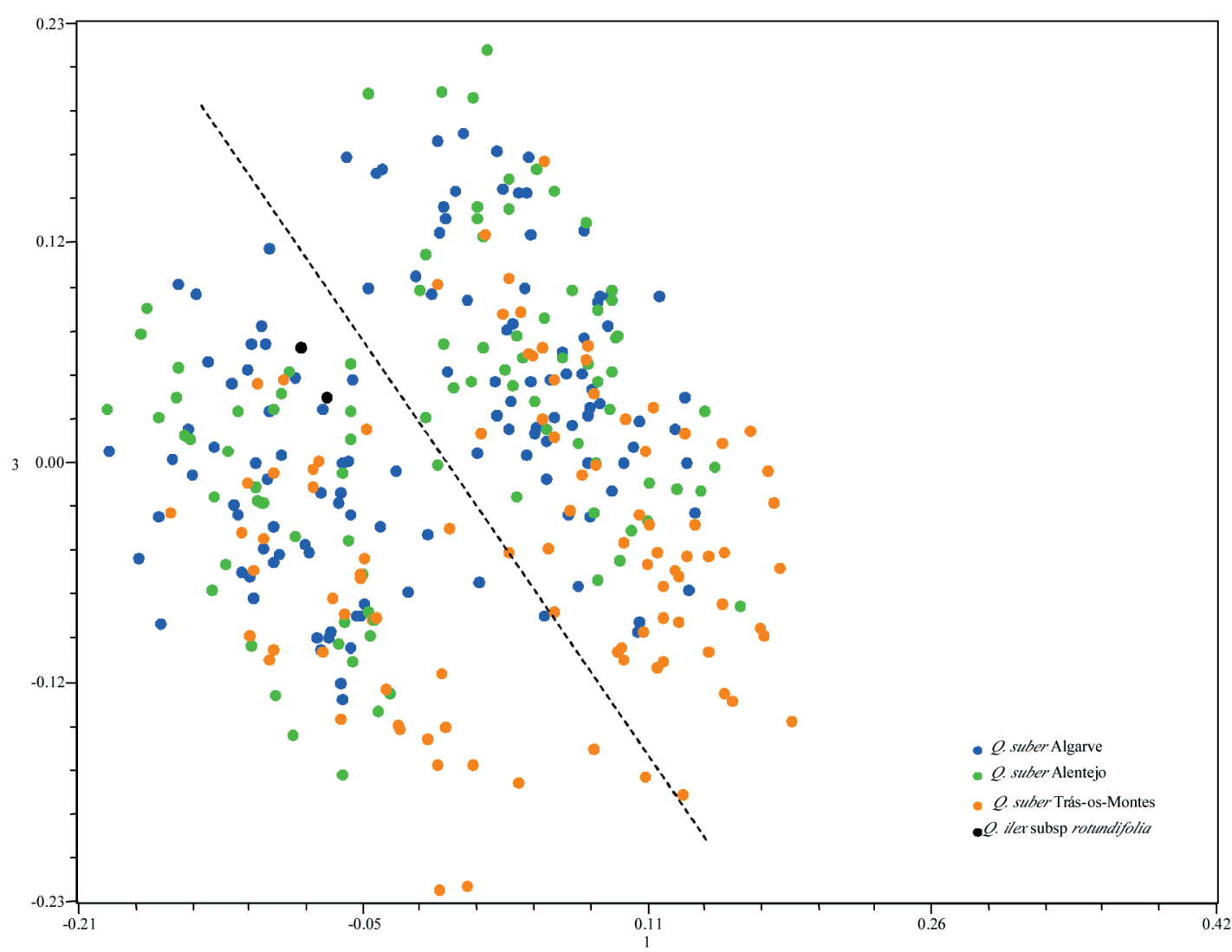

Figure 4. - Projection of the 315 oak trees onto the plane defined by the principal coordinates 1 and 3. 


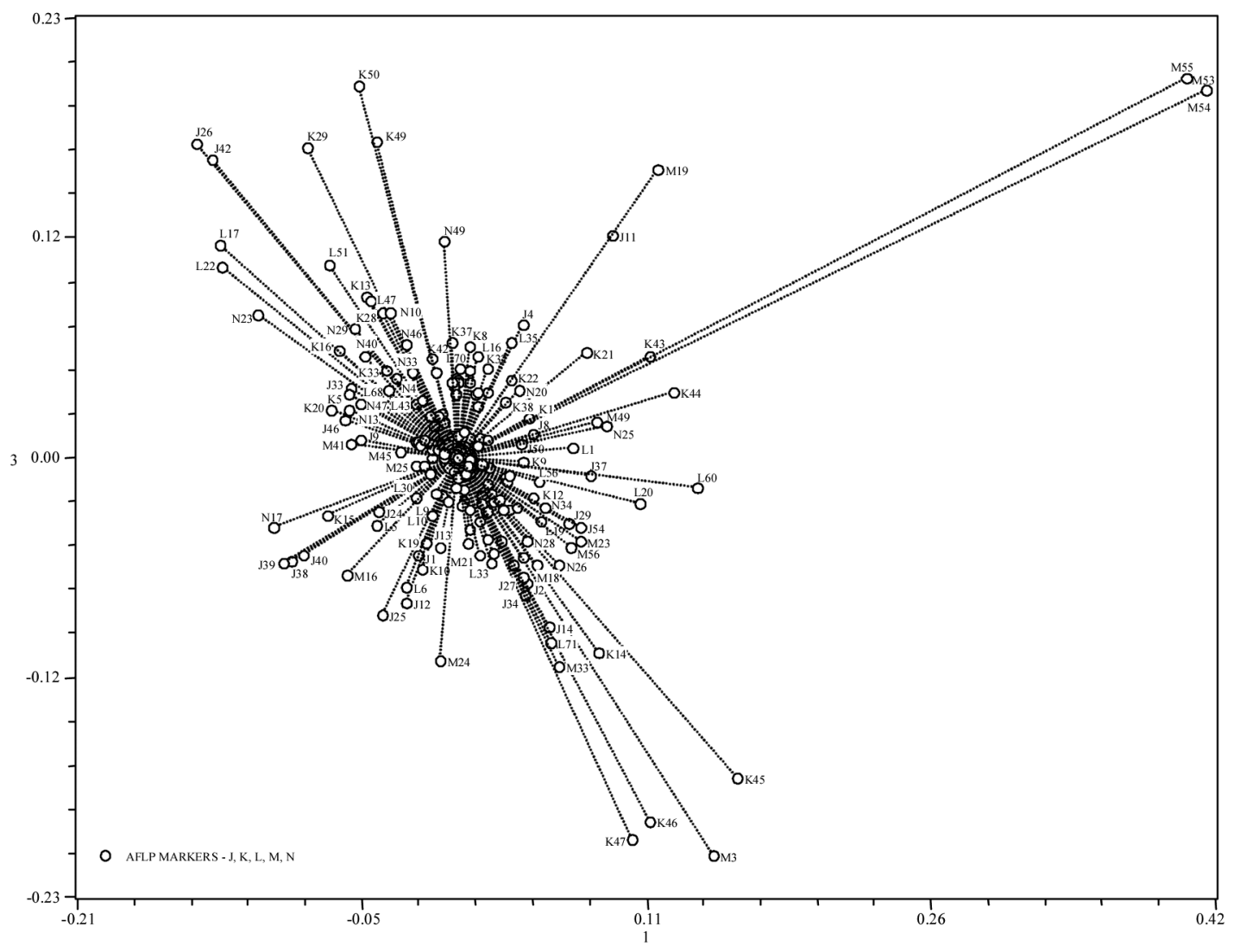

Figure 5. - Projection of the 291 characters onto the plane defined by the principal coordinates 1 and 3.

associated to axis one that have influenced this arrangement in the bi-dimensional space: M41, J9, M45, M25, N17, K15, J39, J38, J40, J24, L5, M16, J25, J12, K37, K8, L16, J4, L35, J11, M19, K22, N20, K21, K43, M55, M53, M54, K1 and J8 (Fig. 5). In spite of the general dispersion observed cork oak trees located in Trás-osMontes tend to occupy a defined area in the graph. The markers that accounted more for this distribution were J2, J14, J27, J29, J34, J54, K14, K45, K46, K47, L33, L71, M3, M18, M23, M33, M56 and N26.

Differentiation of $\mathrm{Q}$. suber and $\mathrm{Q}$. ilex subsp. rotundifolia genotypes

In natural populations of mixed stands of $Q$. suber and $Q$. ilex subsp. rotundifolia, dominated by cork oak, 313 cork oak trees and 52 holm oak trees were analysed using the selective primer combination I9 (EcoRIACC/MseI-TGG). In $Q$. suber fifteen AFLP fragments out of 56 are monomorphic and two of these markers, M31 and M50 are present in the 365 trees, being shared by both species (Fig. 2). Thirty nine fragments (70\%) are polymorphic in $Q$. suber accessions; markers M1, M2, M5, M6, M9, M17, M25, M29 and M37 are present in less than $10 \%$ accessions; three of them, M6, M29 and M37 (Fig. 2), prevail in Q. ilex subsp. rotundifolia accessions. M9, M29 and M37 were frequent (ca 90\%) in the genotype of holm oak individuals and rare in $Q$. suber accessions. For example, in the Algarve region eleven $(3.5 \%)$ cork oak trees having marker M29 were identified. The nucleotide sequence of marker M29 was determined and compared with Database's DNA sequences with fastA program included in GCG Software (Genetic
Computer Group, University of Wisconsin, Madison, 1981). The M29 fragment is $273 \mathrm{bp}$ long and shows a homology of $59 \%$ with the RHC18 gene from Saccharomyces cerevisiae (GeneBank identification number: X80930) over 177 bp. The RHC18 gene codes for a predicted protein of the SMC family implicated in DNA repair pathway for removal of UV- induced DNA damage that is distinct from classical nucleotide excision repair (LEHMANN et al., 1995).

The data matrix I9C (56 fragments AFLP x 365 trees) was analysed using numerical taxonomy methodology. The principal coordinates analysis clustered the 365 accessions into four distinct groups (Fig. 6). Groups I9CIIS1 and I9C-IIS2 are compact and composed exclusively of cork oak trees; the group I9C-IIA comprises $52 Q$. ilex subsp. rotundifolia accessions. Two accessions formed a distinct holm oak cluster (I9C-I). Q. suber and $Q$. ilex subsp. rotundifolia genotypes were identified as belonging to discrete clusters.

The superimposition of the Minimum Spanning Tree (MST) on the projection of the objects shows that all cork oak trees belonging to groups I9C-IIS1 and I9CIIS2 are connected to each other and connected to the I9C-IIA group through one cork oak accession from I9CIIS2 and one holm oak accession from I9C-IIA (Fig. 6). The formation of $Q$. suber (I9C-IIS1 and I9C-IIS2) and Q. ilex subsp. rotundifolia (I9C-IIA and I9C-I) groups is related to axis 1 coordinate. The axis 2 coordinate contrasts groups I9C-IIS1 and I9C-IIS2. The AFLP fragments that accounted for the formation of these groups were identified by projecting the 56 molecular markers onto the plane defined by the axes 1 and 2 (Fig. 7). The 
markers M6, M29, M37, M23, M9 and M25 associated with the axis 1 account for the formation of the group I9C-IIA. The remaining AFLP markers associated with axis 1 account for the formation of group I9C-IIS and are projected in the opposite direction of groups I9C-1 and I9C-IIA.

A phenogram was constructed on the basis of the similarity matrix representing the Jaccard coefficient by using the UPGMA algorithm with a cophenetic correlation of 0.96854 . The cluster analysis divided the 365 genotypes into two distant groups designated I9C-I and I9C-II (Fig. 8). The group I9C-II is subdivided in two groups consisting of $Q$. ilex subsp. rotundifolia (I9C-IIA, dotted) and $Q$. suber individuals (I9C-IIS). Within the Q. suber cluster (I9C-IIS), two distinct subgroups (I9CIIS1, dashed and I9C-IIS2, lined) were formed. Six

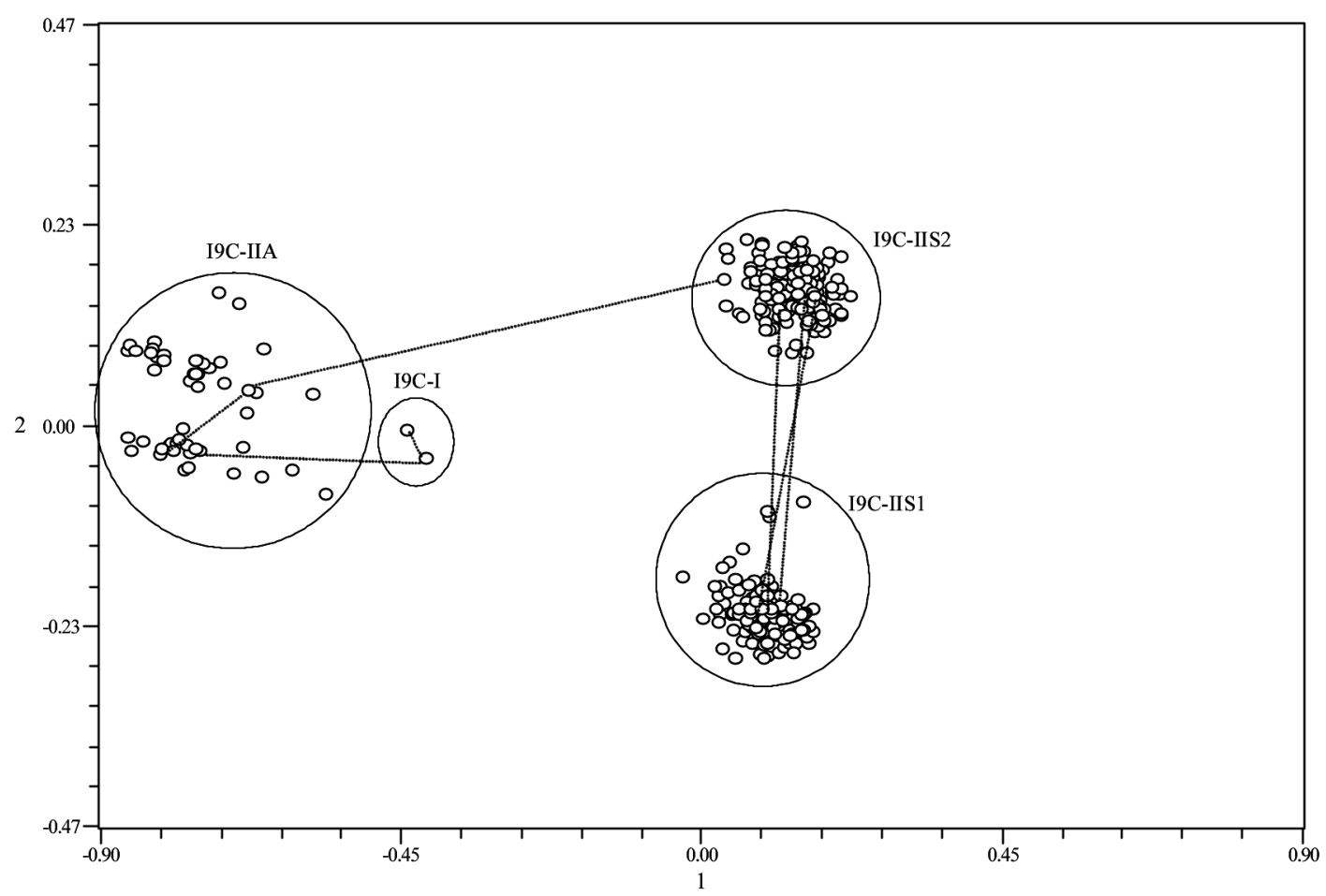

Figure 6. - Projection of the 365 oak trees onto the plane defined by the principal coordinates 1 and 2 .

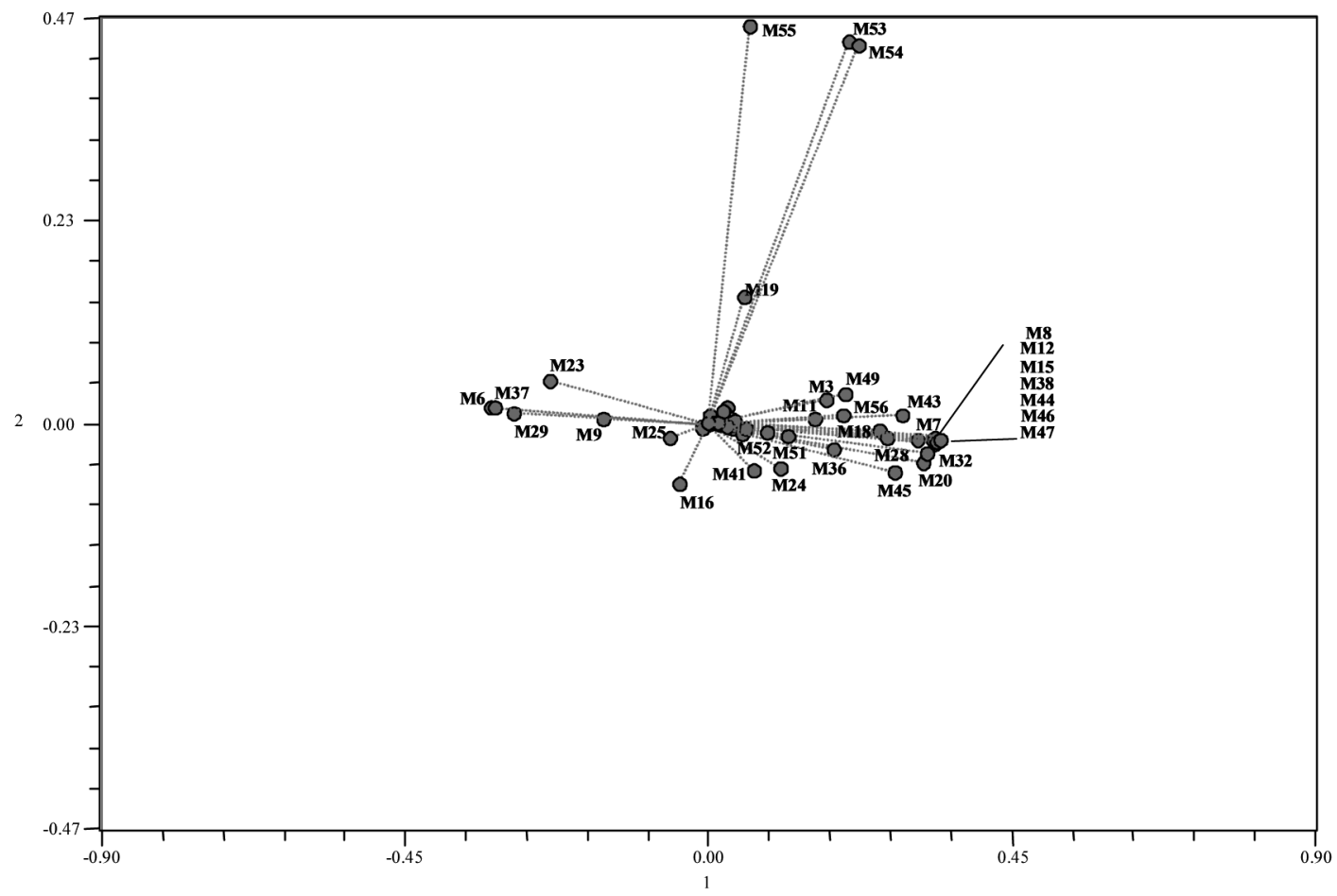

Figure 7. - Projection of the 56 characters onto the plane defined by the principal coordinates 1 and 2. 

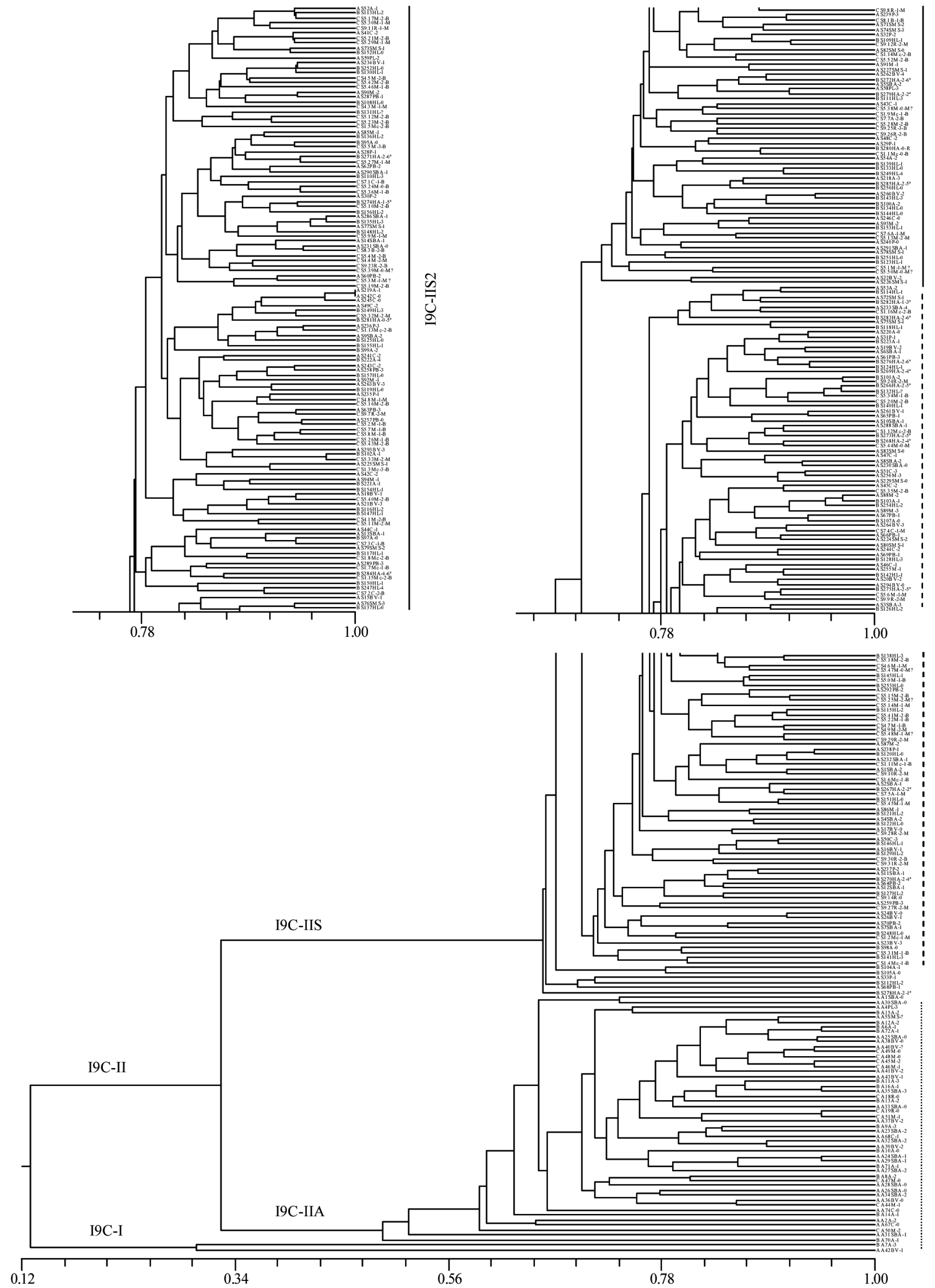

Figure 8. - Phenogram produced by Jaccard's coefficient and the UPGMA clustering method based on 56 AFLP markers in 313 cork oak and 52 holm oak accessions (coefficient of cophenetic correlation $\mathrm{r}=0.96854$ ). 
Q. suber accessions could not be identified as belonging to a discrete group. Two holm oak accessions clustered into group I9C-I are linked to cluster I9C-II at a very low similarity coefficient (0.10).

This phenogram is coherent with the results from principal coordinates analysis. $Q$. suber and $Q$. ilex subsp. rotundifolia individuals were clearly differentiated by AFLP fingerprinting in spite of the existence of markers shared by both species that apparently did not affect the taxonomical identification.

A Bayesian based analysis (Aflpsurv programme) of the population genetic structure, using the AFLP data obtained with the primer combination (I9) for the populations of the two species indicated a clear differentiation between cork oak and holm oak $(F s t=0.4670$, $P<0.001$ ). The AMOVA of the population genetic structure for the same populations corroborated this result ( ct $=0.635, \mathrm{P}<0.001$, Table 3). Most of the nuclear gene diversity is due to species differentiation (64\%); the remaining is distributed within populations (35\%); and $1 \%$ corresponds to the variation among populations within species. These results are in agreement with the organization of the species presented in the phenogram resulting from the hierarchical cluster analysis (UPGMA) that clearly separates $Q$. suber and $Q$. ilex subsp. rotundifolia individuals into two differentiated groups.

\section{Discussion}

\section{Genetic diversity within and among populations}

The AFLP analysis of 313 cork oak trees from natural stands covering main cork productive areas from contrasting regions of Portugal enabled to uniquely fingerprint all the genotypes. The genetic profile of each cork oak resulted from the analysis of 291 loci of the genome, present as polymorphic and monomorphic fragments. The high genetic diversity found in $Q$. suber revealed by the degree of polymorphism (71\%) is in accordance with the morphological diversity observed in fruits, leaves, cork and reproductive structures largely described by NATIVIDADE (1950).

The level of genetic variation evaluated by allozymes analysis is dependent on the enzymatic system used and found to be consistently high within populations (JIMÉNEZ et al., 1999; TOUMI and LUMARET, 1998; ElENARosselló and CABRERA, 1996). However, the inter-population genetic differentiation was found to be low, rang- ing from 3 to $16 \%$. Allelic diversity has also been assessed by analysis with 13 microsatellite carried out on 49 cork oak trees and found to be higher than those obtained with allozyme analysis (HORNERO at al., 2001b).

The results obtained with AFLP markers can not be directly compared with those from other techniques (isozymes, SSR) due to the abundance of loci that are analysed randomly distributed throughout the genome and to the dominant inheritance character of AFLP markers. However, it has been shown for $Q$. petraea and $Q$. robur that when all AFLP markers, polymorphic and monomorphic, are used in a comparative analysis with microsatellite markers, comparable levels of diversity between populations are obtained (MARIETTE et al., 2002).

AFLP markers have been used to investigate nuclear genetic diversity and genetic differentiation within and among oak populations, namely in $Q$. petraea and Q. robur, from seven mixed stands distributed over six European countries (MARIETTE et al., 2002), from indigenous Flemish populations (COART et al., 2002), and in California red oaks (DodD and KASHANI, 2003). The value of AMOVA obtained for the genetic differentiation among populations in $Q$. suber in Portugal $(\Phi s t=0.036)$ is within the range of values reported for those species (0.044-0.030 for oaks over a large European range, 0.021 for Flemish oaks, 0.106 to 0.342 for California red oaks). KREMER and PETIT (1993) reported values from 0.02 to 0.17 for 33 oak species using allozymes markers, HAMRICK et al. (1992) found a mean value of 0.11 for 28 oak species and AlFONSO-CORRADO et al. (2004) values of 0.13 and 0.19 for two Mexican oaks, using RAPD's markers.

The genotypic variance within populations of $Q$. suber $(94 \%)$ is probably underestimated because the AMOVA method, when applied to AFLP markers, assumes that individuals are haploids and that there is fixed homozygosity. It is considered that the marker present in the AFLP profile is homozygous for the corresponding marker locus. However, in case of heterozygosity for this locus the allele frequency will be lower. This method can give significant biased estimates (large overestimation of the frequencies of the marker alleles) when applied to random mating populations with diploid genotypes. As expected the value of genetic differentiation among populations computed by Aflpsurv programme (Fst = $0.0172 ;$ Fis $=0.150$ ) is lower than that obtained with AMOVA. Indeed, the Bayesian approach allows the

Table 3. - Partition of variation in AFLP fragment patterns between cork oak and holm oak.

\begin{tabular}{|c|c|c|c|c|c|c|}
\hline Source of variation & d.f. & $\begin{array}{l}\text { Sum of } \\
\text { squares }\end{array}$ & $\begin{array}{c}\text { Variance } \\
\text { components }\end{array}$ & $\begin{array}{l}\text { Percentage } \\
\text { of } \\
\text { variance }\end{array}$ & $\Phi$ values & P value \\
\hline \multicolumn{7}{|c|}{$\begin{array}{l}\text { AMOVA of the AFLP data obtained with primer combination I9 for } 313 \text { cork oak individuals and } 52 \text { holm } \\
\text { oak individuals. }\end{array}$} \\
\hline Between species & 1 & 742.892 & 8.25470 & 63.56 & $\Phi \mathrm{ct}=0.635$ & $<0.001$ \\
\hline $\begin{array}{l}\text { Among populations } \\
\text { within species }\end{array}$ & 26 & 170.995 & 0.16106 & 1.24 & $\Phi \mathrm{sc}=0.034$ & $<0.001$ \\
\hline Within populations & 337 & 1540.688 & 4.57178 & 35.20 & $\Phi \mathrm{st}=0.648$ & $<0.001$ \\
\hline Total & 364 & 2454.575 & 12.98754 & & & \\
\hline
\end{tabular}


incorporation of uncertainty about the magnitude of within-population inbreeding coefficients into estimates of $F s t$, and is supposed to give more accurate results.

Low levels of differentiation among oak populations is due to the outcrossing characteristic of the species (the case of $Q$. suber, BOAVIDA et al., 2001), long distance anemophilous pollination mechanism and eventual secondary acorn dispersal by animals, leading to extensive gene flow and increased homogeneity of allele frequency among populations. The values of population differentiation disclosed in the present work, for $Q$. suber $(F s t=$ $0.0172 ; \Phi s t=0.036)$ are below the average of 0.07-0.09 expected for long-lived, wind-pollinated woody species (HAMRICK and GODT, 1989). This pattern of genetic differentiation of Portuguese cork oaks from stands, some located over a distance of 700 kilometres, may be explained by anthropogenic pressure in addition to the effect of gene flow. In fact continued human intervention has been systematically pursued over at least seven centuries aiming at the increasing of cork production and quality. A decreasing of the effective population size of cork oak regarding to holm oak, as the outcome of a possible acorn production oriented management would result in less genetic diversity. This supposition is reasonable as holm oak acorns are preferred to feed livestock. However, until cork began to be exploited in $14^{\text {th }}$ century oak forests were reserved for hunting by sovereigns. Barking and acorn utilization were forbidden, hence it is logical to admit that selection for cork quality has preponderated over selection for acorn used to feed livestock.

A previous study directed mainly to Spanish populations (14) that included only one population of $Q$. suber from Portugal using isozymes analysis pointed to the homogenisation of the genetic structure of the species due to existence of gene flow between populations (JIMÉNEZ et al., 1999).

The present study shows that $90 \%$ of the polymorphic markers identified in cork oak genotypes are uniformly distributed through the populations of Algarve, Alentejo and Trás-os-Montes regions. This homogeneity is visible in the phenogram (Fig. 3) where clearly distinct groups associated with a geographic localisation are absent, although some cork oak trees with the same geographic localisation appear clustered together. In Portugal where the most productive areas worldwide are located, stand plantations with trees of controlled origin parallel to those that are the result of natural regeneration. The results are in agreement with those obtained with AMOVA.

The genetic similarity coefficients vary from 0.61 to 0.88 showing that all individuals analysed share $60 \%$ of similarity forming a large unique group subdivided in several small groups (Fig. 3). However, the principal coordinates analysis shows a tendency for the separation of the 313 cork oak trees in two groups without apparent correspondence with the geographic location. Cork oak trees from Trás-os-Montes region exhibit a slightly lower dispersion on the bi-dimensional plot of the principal coordinates than those from other regions (Fig. 4). This observation is not surprising as stands located in the northern region of Trás-os-Montes are geographically well separated from central and southern regions and no stands subsist in the intermediate region.

\section{Introgression between Q. suber and Q. ilex subsp. rotundifolia}

The genetic profiles of the 52 individuals of holm oak were performed with the same five primer combinations used to analyse cork oak. However, the score of the fragments was only possible with the combination I9 because the other four primer combinations included a much higher number of fragments than that present in cork oak profiles rendering the score of the fragments impracticable. The level of similarity observed between the profiles of the individuals from holm oak species showed to be lower than in cork oak, implying that apparently the degree of polymorphism detected in $Q$. ilex subsp. rotundifolia is higher than that quantified in $Q$. suber. To study the genetic structure of $Q$. ilex subsp. rotundifolia by AFLP analysis it would be necessary to use primer combinations with different selective nucleotides. This was not within the scope of the present work. Our observations are in agreement with those from TOUMI and LUMARET (1998) in 40 populations from the western Mediterranean Basin. Using allozyme polymorphism analysis the authors have found that cork oak possessed a smaller allele pool than holm oak and a lower average number of alleles per locus and per population but had a higher total genetic variation and within-population genetic diversity.

Natural cross breeding of cork oak with holm oak leading to intermediate phenotypes whose offspring produced a high variety of transition forms among periderms of cork oak and holm-oak has been suggested on the basis of systematic phenotype observation (NATIVIDADE, 1936).

Recent observations of shared cytoplasmatic DNA based on chloroplast and mitochondrial analysis by PCR-RFLP, concerning $Q$. suber and $Q$. ilex, showed that hybridization between the two species actually does take place with intogression being more frequent in the direction $Q$. ilex (female) x $Q$. suber (male) (JIMÉNEZ et al., 2004; BeLAHBIB et al., 2001). However, this asymmetric hybridization appears to be uncommon due to rare phenological overlap, to unidirectional compatibility or strong pollen-stigma interactions and to competitive disadvantage of interspecific pollen tubes (BOAVIDA et al., 2001). Introgression of holm oak into cork oak has also been detected by allozyme analysis (Toumi and LUMARET, 1998).

Interspecific shared AFLP fragments may originate through genetic introgression although a plesiomorphic origin of fragments can not be excluded. AFLP fragments M9, M29 and M37 produced with primer combination I9 were frequent (ca 90\%) in the genotype of holm oak individuals and rare in that of cork oak trees. As an example M29 was uncovered in $3.5 \%$ of cork oak trees in the Algarve region and sequenced. The homology found with proteins of the SMC family involved in DNA repair pathway for removal of UV- induced DNA damage suggests that M29 belongs to a $Q$. suber gene 
whose acquisition might have originated from hybridization with $Q$. ilex subsp. rotundifolia, which gives some advantage in terms of a potential adaptation to areas with important solar exposure.

It is possible that some AFLP fragments originate from organelle DNA. However, no homologies were found between 16 AFLP fragments that were sequenced (including M29) and genes from organelle genomes (results not shown). Ten of these AFLP fragments were homologous to sequences of genomic DNA of Arabidopsis thaliana or Oryza sativa and the others present homology with Solanum tuberosum proteinase inhibitor I gene, Arabidopsis thaliana dihydroflavonol 4-reductase gene, Oryza sativa microsatellite, Solanum tuberosum alcohol dehydrogenase 1 gene and Lycopersicon esculentum putative permease gene.

\section{Diagnostic AFLP markers for cork quality}

Due to its very slow growth and impracticality of being vegetatively propagated cork oak can not be easily multiplied for use in some experimental purposes such as Bulked Segregant Analysis, a method which facilitates the identification of markers linked to QTL's. The factors that influence cork quality are controversial as little is known about the relative weight of environmental and genetic constraints. Nevertheless, following cluster analysis by UPGMA, we have identified trees classified as producers of cork of good quality that clustered together. Four AFLP markers common to these trees were disclosed. Even though they are not specific to this group, it is not excluded that fragments observed in other cork oak trees may correspond to nonhomologous AFLP fragments of the same size. The significance of these potential markers is for the moment not known and further studies including sequencing will help to elucidate their real meaning.

\section{Acknowledgments}

This work was financed by the EC-III Framework Programme for Research and Technological Development, cofinanced by the European Social Fund (ESF) and by national funding from Ministério da Ciência e do Ensino Superior (MCES) (POCTI/AGR/34389/2000). We also thank NATO (SfS PO-CORKOAKS II) for financial support.

\section{References}

Alfonso-Corrado, C., R. Esteban-Jiménez，R. ClarkTAPIA, D. PiÑERo, J. E. CAMPos and A. Mendoza (2004): Clonal and genetic structure of two Mexican oaks: Quercus eduardii and Quercus potosina (Fagaceae). Evolutionary Ecology 18: 585-599.

Bacilieri, R., A. Ducousso, R. J. Petit and A. Kremer (1996): Mating system and asymmetric hybridization in a mixed stand of European oaks. Evolution 50: $900-908$.

BARRos Bernardo, H. (1942): Economia Corticeira dos séculos XV e XVI, Bol. Junta N. Cortiça, ano IV, 43: $15-16$.

Belahbib, N., M-H., Pemonge, A. Ouassou, H., Sbay, A. KREMER and R. J. PETIT (2001): Frequent cytoplasmic exchanges between oak species that are not closely related: Quercus suber and Q. ilex in Marocco. Molecular Ecology 10: 2003-2012.

BoAvidA, L. C. , J. P. Silva and J. A. FeiJó (2001): Sexual reproduction in the cork oak (Quercus suber L). II. Crossing intra- and interspecific barriers. Sex Plant Reprod. 14: 143-152.

Brasier, C. M., F. Sobredo and J. F. P. Ferraz (1993): Evidence for Phytophthora cinnamomi involvement in Iberian oak decline. Plant Pathology 42: 140-145.

CAMus, A. (1938): Les chênes, Monographie du genre Quercus, Paris, France: Lechevallier; vol. 3.

Cervera, M. T., J. Gusmão, M. Steenackers, J. Peleman, V. Storme, A. Vanden Broeck, M. Van Montagu and W. BOERJAN (1996): Identification of AFLP molecular markers for resistance against Melampsora larici-populina in Populus. Theor. Appl. Genet. 93: 733-737.

Coart, E., V. Lamote, M. De Loose, E. Van Bockstaele, P. LOOTENS and I. ROLDÁN-RUIZ (2002): AFLP markers demonstrate local genetic differentiation between two indigenous oak species [Quercus robur L. and Quercus petraea (Matt.) Liebl.] in Flemish populations. Theor. Appl. Genet. 105: 431-439.

Cottrell, J. E., R. C. Munro, H. E. Tabbener, A. D. MilNER, G. I. FORREST and A. J. LowE (2003): Comparison of fine-scale genetic structure using nuclear microsatellites within two British oakwoods differing in population history. For. Ecol. and Manage 176: 287-303.

DoDD, R. S. and N. KASHANI (2003): Molecular differentiation and diversity among the Californian red oaks (Fagaceae; Quercus section Lobatae). Theor. Appl. Genet. 107: 884-892.

Elena-Rosselló, J. A., R. Lumaret, E. CABrera and H. MichaUd (1992): Evidence for hybridization between sympatric holm-oak and cork-oak in Spain based on diagnostic enzyme markers. Vegetatio 99-100: 115-118.

Elena-Rosselló, J. A. and E. CABRERA (1996): Isozyme variation in natural populations of cork-oak (Quercus suber L.) Population structure, diversity, differentiation and gene flow. Silvae Genetica 45: 229-235.

Excoffier, L., Smouse, P. E. and J. M. QuATtro (1992): Analysis of molecular variance inferred from metric distances among DNA haplotypes: application to human mitochondrial DNA restriction data. Genetics 131: 479-491.

Fonseca, F. M. A., J. L. P. C. Louzada, M. E. C. M. Silva, and C. A. M. Gomes (1992): Determinação da porosidade da cortiça com sistema de análise de imagens por computador e estudo preliminar da sua variação por classes de qualidade. Proceedings of Simpósio Mediterraneo sobre Regeneración del Monte Alconorcal, Mérida, Spain.

Gower, J. C. and G. J. S. Ross (1969): Minimum spanning tree and single-linkage cluster analysis. Applied Statistics 18: 54-64.

HAMRICK, J. L. and M. J. W. GoDT (1989): Allozyme diversity in plant species. In: A. H. D. Brown, M. T., ClegG, A. L. KAHLER and B. S. WeIR (eds.) Plant Population Genetics, Breeding and Genetic Variations in Plants. Sunderland, Massachusetts, USA, pp. 43-63

Hamrick, J. L., M. J. W. Godt and S. L. Sherman-Broyles (1992): Factors influencing levels of genetic diversity in woody plant species. In: AdAms, W. T., Strauss, S. H., Copes, D. L., Griffin, A. R. (eds). Population genetics of forest trees. Kluwer Academic Publishers, Dordrecht, 31-36.

HARDIN, J. W. (1975): Hybridization and introgression in Quercus alba. J. Arnold Arbor Harv. Univ. 56: 336-363. 
Hornero, J., I. Martinez, C. Celestino, F. J. Gallego, V. TORRes and M. TORIBIO (2001a): Early checking of genetic stability of cork oak somatic embryos by AFLP analysis. Int. J. Plant Sci. 162 (4): 827-833.

Hornero, J., F. J. Gallego, I. Martinez and M. Toribio (2001b): Testing the conservation of Quercus spp Microsatellites in the cork oak, Q. suber L. Silvae Genetica 50: 162-167.

Howard, D. J., R. W. Preszler, J. Williams, S. Fenchel and W. J. BoECKLEN (1997): How discrete are oak species? Insights from a hybrid zone between Quercus grisea and Quercus gambelii. Evolution 51: 747-755.

JiMÉNEZ, P., D. AGúnDEZ, R. AlíA and L. GIL (1999): Genetic variation in central and marginal populations of Quercus suber L. Silvae Genetica 48: 278-284.

JimÉNEZ, P., U. LÓPEZ DE HEREDiA, C. COLladA, Z. LORENZO and L. GIL (2004): High variability of chloroplast DNA in three Mediterranean evergreen oaks indicates complex evolutionary history. Heredity 1-6.

Kremer, A. and R. J. Petit (1993): Gene diversity in natural populations of oak species. Ann. Sci. For. 50 (Suppl. 1): $186 \mathrm{~s}-202 \mathrm{~s}$.

Lebreton, P., M. Barbéro and P. Quézel (2001): Contribution morphométrique et biochimique à la structuration et à la systématique du complexe spécifique Chêne vert Quercus ilex L. Acta Bot. Gallica 148 (4): 289-317.

Lehmann, A. R., M. Walicka, D. J. F. Griffiths, J. M. Murray, F. Z. Watts, S. MCCready and A. M. CARR (1995): The rad18 gene of Schizosaccharomyces pombe defines a new subgroup of the SMC superfamily involved in DNA repair. Mol. and Cell. Biol. 15 (12): 7067-7080.

Mace, E. S., C. G. Gebhardt and R. N. Lester (1999): AFLP analysis of genetic relationships in the tribe Datureae (Solanaceae). Theor. Appl. Genet. 99: 634-641.

Mariette, S., J. Cottrell, U. M. Csaikl, P. Goihoechea, A. König, A. J. Lowe, B. C. VAn Dam, T. BarReneche, C. Bodénès, R. Streiff, K. Burg, K. Groppe, R. C. Munro, H. TABbener and A. Kremer (2002): Comparison of levels of genetic diversity detected with AFLP and microsatellite markers within and among mixed Q. petraea (Matt) Liebl and Q. robur L. stands. Silvae Genetica 51: 72-79.

Mattoso, A. G. (1947): O sobreiro- Da humildade à opulência. Bol. Junta N. Cortiça. Ano IX: 123-346.

Moreira-Marcelino, A. C. (2001): Aspectos da interacção entre Phytophthora cinnamomi e a doença do declínio em Quercus suber e Quercus rotundifolia. Faro, Portugal: University of Algarve, $\mathrm{PhD}$ thesis.

Moreira, A. C. and J. M. S. MARTins (2005): Influence of site factors on the impact of Phytophthora cinnamomi in cork stands in Portugal For. Path. 35: 145-162.

MULLER, C. H. (1952): Ecological control of hybridization in Quercus: A factor in the mechanism of evolution. Evolution 6: 147-161.

NATIVIDADE, J. V. (1936): Estudo histológico das peridermes do híbrido Quercus ilex x suber. P Cout. Publ Dir G Serv Flor e Aquícolas 3(1): 343-368.

Natividade, J. V. (1950): Subericultura, Ministério da Agricultura, Lisboa.

Newton, A. C., T. R. Allnutt, A. C. M. Gillies, A. J. Lowe and R. A. Ennos (1999): Molecular phylogeography, intraspecific variation and the conservation of tree species. Tree 14: 140-145.

PALmer, E. J. (1948): Hybrid oaks of North America. J. Arnold Arbor Harv. Univ. 29: 1-48.
Paul, S., F. N. Wachira, W. Powell and R. WAUGH (1997): Diversity and genetic differentiation among populations of Indian and Kenyan tea (Camellia sinensis (L.) O Kuntze) revealed by AFLP markers. Theor. Appl. Genet. 94: 255-263.

RoHLF, F. J. (1998): NTSYS-pc, Numerical Taxonomy and Multivariate Analysis, version 2.0. Exeter Software. Setauket, New York.

Rushton, B. S. (1993): Natural hybridization within the genus Quercus L. Ann. Sci. For. 50 (Suppl 1) 50: $73 \mathrm{~s}-90 \mathrm{~s}$.

SchneIder, S., D. Roessli and L. Excoffier (2000): Arlequin version 2.000. A software for population genetics data analysis. Genetics and Biometry Laboratory, Department of Anthropology and Ecology, University of Geneva, Geneva, Switzerland.

Singh, A., M. S. Negi, J. Rajagopal, S. Bhatia, U. K. TOMAR, P. S. SRIVASTAVA and M. LAKSHMIKUMARAN (1999): Assessment of genetic diversity in Azadirachta indica using AFLP markers. Theor. Appl. Genet. 99: $\overline{272-279}$

Sneath, P. H. A. and R. R. Sokal (1973): Numerical Taxonomy The principles and practice of numerical classification. W. H. FreEman and Co., San Francisco.

SPELlenBerg, R. (1995): On the hybrid nature of Quercus basaseachicensis (Fagaceae, sect Quercus). Sida 16: 427-437.

Thomas, C. M., P. Vos, M. Zabeau, D. A. Jones, K. A. NorCOTT, B. P. CHADWICK and J. D. G. Jones (1995): Identification of amplified restriction fragment polymorphism (AFLP) markers tightly linked to the tomato Cf-9 gene for resistance to Cladosporium fulvum. The Plant Journal 8 (5): 785-794.

TOUmi, L. and R. Lumaret (1998): Allozyme variation in cork oak (Quercus suber L.): the role of phylogeography and genetic introgression by other Mediterranean oak species and human activities. Theor. Appl. Genet. 97: 647-656.

TOUMI, L. and R. LuMARET (2001): Allozyme characterisation of four Mediterranean evergreen oak species. Biochemical Systematics and Ecology 29: 799-817.

Trelease, W. (1924): The American oaks. Mem. Natl. Acad. Sci. 20: 1-255.

VAn Der Merwe, M., M. O. Winfield, G. M. Arnold and J. S. PARKER (2000): Spatial and temporal aspects of the genetic structure of Juniperus communis populations. Molecular Ecology 9: 379-386.

VEKEMANS, X. (2001): AFLPsurv V.1.0 a software for genetic diversity analysis with AFLP population data, distributed by the author, xvekema@ualb.ac.be, Université Libre de Bruxelles.

Viterbo, S. (1904): O monopólio da cortiça no século XV. Arch. Hist. Port. II: 41-52.

Vos, P., R. Hogers, M. Bleeker, M. Reijans, T. van DE Lee, M. Hornes, A. Frijters, J. Pot, J. Peleman, M. KuIPER and M. ZABEAU (1995): AFLP: a new technique for DNA fingerprinting. Nucleic Acids Res. 23 (21): 4407-4414.

Zhang, L.-H., P. Ozias-Akins, G. Kochert, S. Kresovich, R. DEAN and W. HANNA (1999): Differentiation of bermudagrass (Cynodon spp) genotypes by AFLP analyses. Theor. Appl. Genet. 98: 895-902.

ZHIVoToskY, L. A. (1999): Estimating population structure in diploids with multilocus dominant DNA markers. Molecular Ecology 8: 907-913. 